DOI: https://doi.org/10.31933/dijdbm.v2i3 Received: 24 January 2021, Revised: 18 March 2021, Publish: 18 March 2021

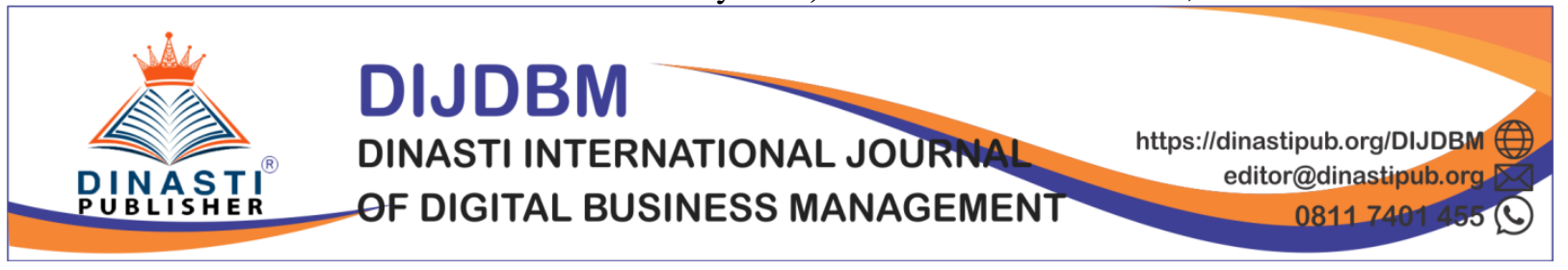

\title{
THE EFFECT OF TRAINING, WORK DISCIPLINE AND ORGANIZATIONAL COMMITMENT ON EMPLOYEE PERFORMANCE AT THE BUILDING PLANT T DEPARTMENT OF TIRE COMPANY IN BANTEN
}

\author{
Abdul Aji Kresna Tri Anggara ${ }^{1}$, Sangkala Ruslan ${ }^{2}$ \\ 1) Master of Management Mercu Buana University Jakarta, Indonesia. \\ ${ }^{2)}$ Master of Management Mercu Buana University Jakarta, Indonesia.
}

\begin{abstract}
The era of globalization has an impact on changes in various aspects, including business competition which has become increasing tightly. More and more competitors and high business competition require organizations to have high knowledge and abilities to be able to compete. Changes that occur due to globalization require companies to be able to establish strategies related to improving performance. Tire manufacturing in Banten is one of companies which are faced with business competition in which the company has fairly tight competitors. The Building Plant, Department $\mathrm{T}$, is one of the parts in the organizational structure of this tire company, where the department is also required to meet the performance indicators set by the company. Many factors affect employee performance including training, work discipline and organizational commitment. This study aims to determine the effect of training, work discipline and organizational commitment on employee performance in tire companies in Banten. This study uses a quantitative approach with data analysis in testing the measurement model and testing the structural model using SmartPLS version 3.2.7 software. The results show that training has a significant effect on employee performance, work discipline has a significant effect on employee performance, organizational commitment has a significant effect on employee performance, and training, work discipline and organizational commitment has a significant effect on employee performance.
\end{abstract}

Keywords: Training, work discipline, organizational commitment and employee performance.

\section{INTRODUCTION}

Tire company in Banten is one of the tire companies that are faced with business competition, where the company has a fairly tight competitor. One of the efforts in business competition is the right human resource system as a very important element in achieving company goals. The company is expected to encourage all employees to contribute in carrying out their tasks and responsibilities.

The Building Plant T Department is one of the parts in the organizational structure of a tire company in Banten, where the department is also required to meet the performance indicators set by the company. Performance indicators Building Department consists of quantity and quality. 
Based on the secondary data obtained, it is known that the performance of employees at the Building Plant T Department is not optimal yet. The following is secondary data on the quantity results of the performance of Building Plant $\mathrm{T}$ Department in the tire company in Banten during January - October 2019 period. Can be seen in Figure 1.

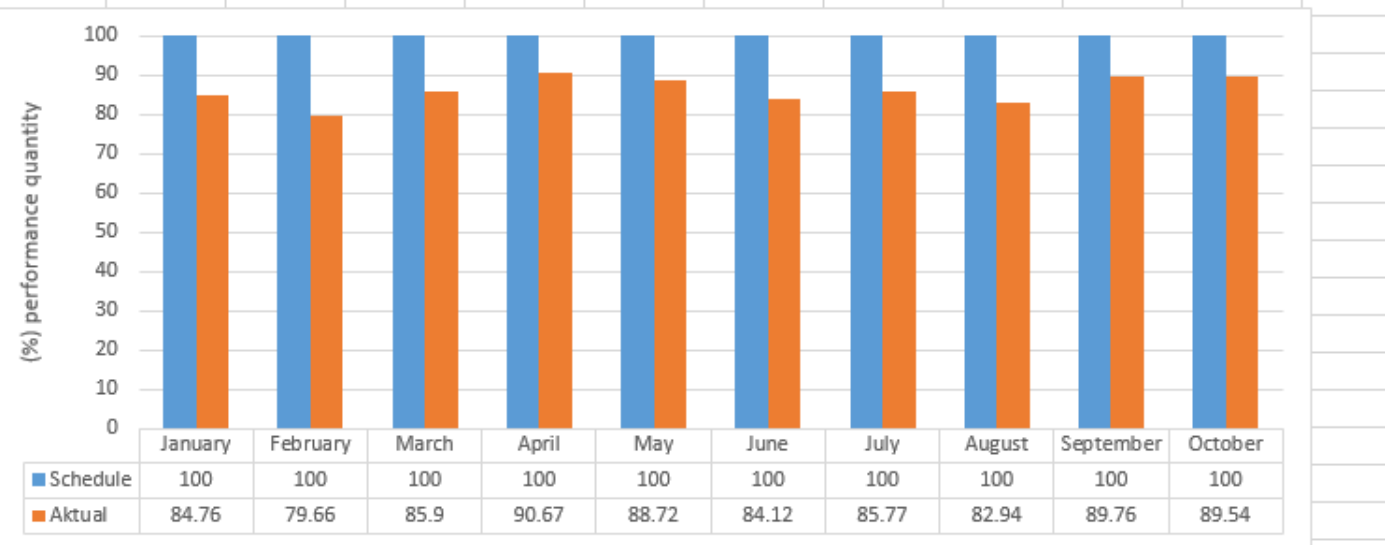

Figure 1. Data of the quantity of production performance in 2019 at the Department Building

Figure 1 shows the quantity performance achievement of the tire company's Building Plant T Department in Banten from January to October 2019. The average output quantity of the department's performance in that range month is $86.18 \%$. This shows that the performance of the Building Plant T Department is less than $100 \%$ and has not reached the target set by the company.

The results of the performance quality of the Building Plant T Department of tire company in Banten during the January - October 2019 period can be seen in Figure 2.

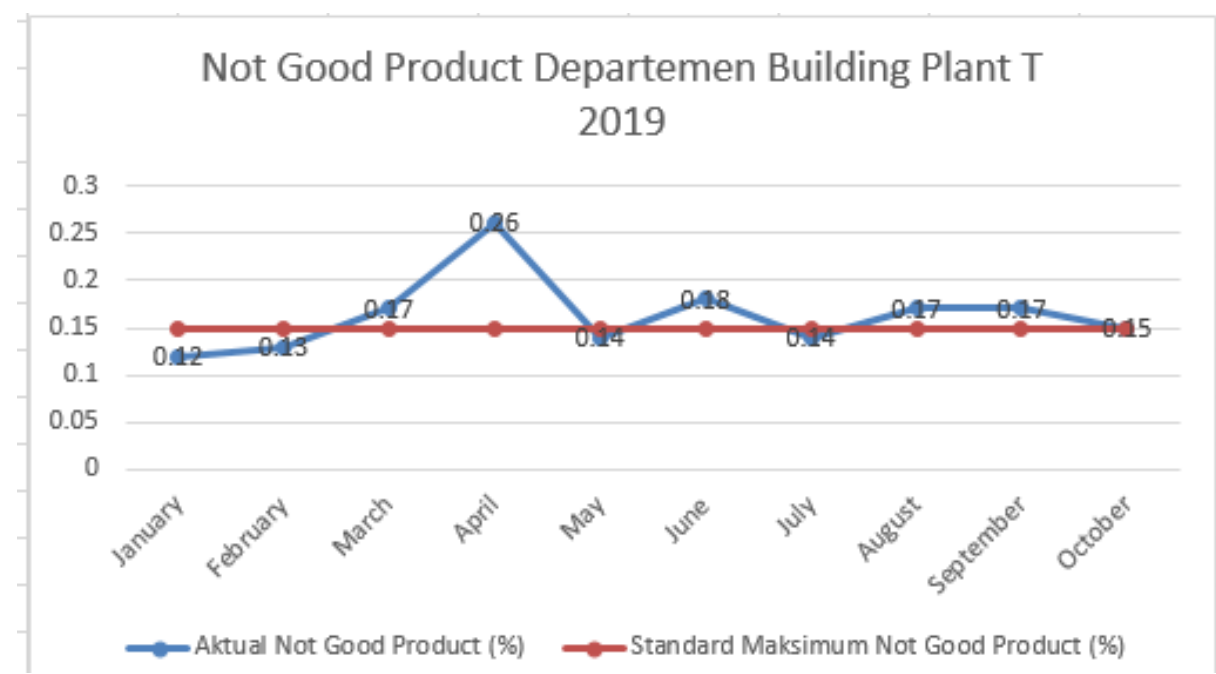

Figure 2. Data of production performance quality in 2019 in the Building Department

Figure 2 shows the results of the production quality performance of the Building Plant T Department from January to October 2019. The average output of not good products produced during that range month is $0.163 \%$, where this value has exceeded the maximum allowable not good product standard of $0.15 \%$. This shows that the quality of the performance of the building plant $\mathrm{T}$ department has not reached the predetermined target. 
There are many factors affecting the performance of the Building Plant T Department employees including quantity and quality. The results of the pre-research show that the factors that affect the performance of the Building Plant $T$ Department of a tire company in Banten are shown in Figure 3. Figure 3 shows that the highest factors affecting the performance of the building department employees are training, work discipline and organizational commitment.

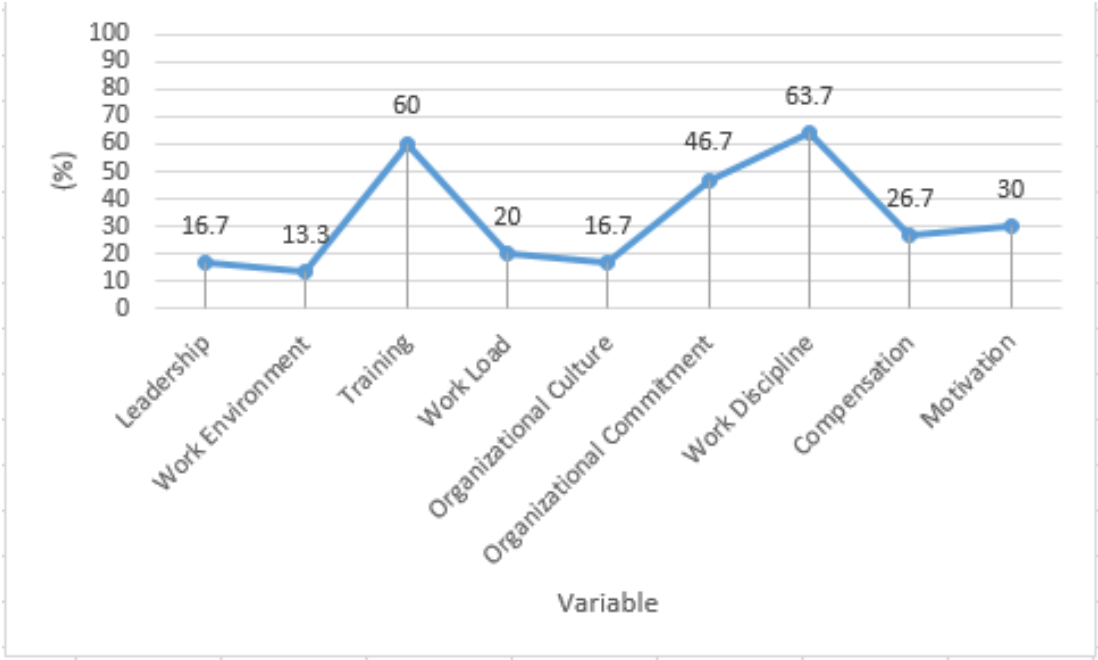

Figure 3. Contribution of variables to performance Source: Data processed by Researchers (2020)

The researcher conducted a study on previous research related to the topic of training, work discipline and organizational commitment to employee performance. The results of the study show a research gap which is presented in Table 1.

Table 1. Research gap observation

\begin{tabular}{|l|l|l|}
\hline \multicolumn{1}{|c|}{ Research gap } & \multicolumn{1}{|c|}{ Researcher } & \multicolumn{1}{|c|}{ Result } \\
\hline $\begin{array}{l}\text { There are differences in the results of } \\
\text { research on the effect of training on } \\
\text { employee's performance. }\end{array}$ & $\begin{array}{l}\text { Jumawan and Mora(2018) } \\
\text { Rahinnaya and Perdhana (2016) }\end{array}$ & $\begin{array}{l}\text { Positive and significant } \\
\text { No effect }\end{array}$ \\
\hline $\begin{array}{l}\text { There are differences in the results of } \\
\text { research on the effect of work discipline on } \\
\text { employee performance }\end{array}$ & $\begin{array}{l}\text { Putri,Triamanto and Setiadi (2017) } \\
\text { Setiawan (2013) }\end{array}$ & $\begin{array}{l}\text { Significant } \\
\text { No effect }\end{array}$ \\
\hline $\begin{array}{l}\text { There are differences in the results of } \\
\text { research on the effect of organizational } \\
\text { commitment on employee performance }\end{array}$ & $\begin{array}{l}\text { Viphaprastha, Sudja and Yuesti } \\
\text { (2018) } \\
\text { Sawitri,Suswati and Huda (2016) }\end{array}$ & $\begin{array}{l}\text { Positive and significant. } \\
\text { Not significant }\end{array}$ \\
\hline
\end{tabular}

Source: data processed by researchers (2020)

Based on this background, researchers are interested in conducting research with the title "The Effect of Training, Work Discipline and Organizational Commitment on Employee Performance".

\section{LITERATURE REVIEW Performance}

According to Fahmi (2010: 2), performance is the result obtained by an organization, whether the organization is profit oriented and non-profit oriented which is generated over a period of time. Performance is also defined as the level of success (output) of a person or 
group in carrying out a task, both in quantity and quality compared to various existing criteria, such as work standards, targets or targets or criteria that have been determined in advance and have been mutually agreed.

\section{Training}

According to Saks and Haccoun (2013: 6), training is a formal and planned effort to help employees acquire knowledge, skills and abilities to improve performance in their current jobs. Training aims to improve employee capabilities and provide valuable intelligence about the core skills needed to achieve predetermined organizational goals.

\section{Work Discipline}

According to Gomez-Meija, Balkin and Cardy (2010: 482), employee discipline is a tool that managers rely on to communicate with employees who can change behavior, such as employees being late for work, neglecting safety procedures, neglecting job details that are required by their work so that behavior is not professional. There is a close relationship related to work discipline as a tool or means for an organization with employee's performance. This is because with high discipline, employees or subordinates will obey all the existing regulations so that the implementation of work can be in accordance with the predetermined plan.

\section{Organizational Commitment}

According to Bateman and Snell (2014: 66), organizational commitment is defined as the degree to which an employee identifies himself with a particular organization and its goals and wishes to maintain its membership in the organization. Employees who have a strong commitment will have a high attachment to their place of work, as evidence of not wanting to leave the workplace because they have high loyalty. This shows that the higher the employee's organizational commitment will have a positive impact on improving performance, employees with high commitment will be responsible for their work. Schermerhorn (2010: 335) states that there are two dimensions of organizational commitment, namely:

a. Rational commitment. Employee feels that the work will provide financial benefits, development and professional interest.

b. Emotional Commitment. Employee feels that what is done is important, valuable and provides benefits to others.

\section{Framework}

Many factors affect employee performance, including training, work discipline and organizational commitment. Based on the description above, the researcher determined several variables that would later be studied, consisting of the independent variable $(X)$, namely Training (X1), Work Discipline (X2) and Organizational Commitment (X3) and the Dependent Variable (Y), namely Employee Performance. So, the framework in this study is as follows: 


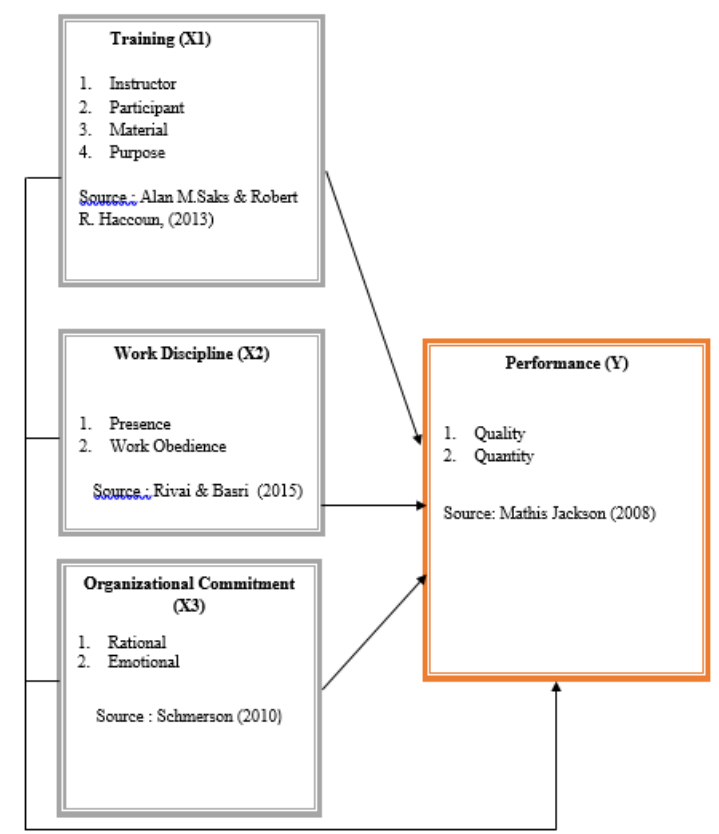

Figure 4. Contribution of variables to performance.

Referring to the framework above, this study wants to know and explain the effect of training, work discipline and organizational commitment on the performance of the employees of the tire company Building Plant T Department in Banten.

\section{Hypothesis}

H1: Training has a significant effect on employee performance

H2: Work discipline has a significant effect on employee performance

H3: Organizational commitment has a significant effect on employee performance

H4: Training, work discipline, organizational commitment have a significant effect on employee performance.

\section{RESEARCH METHODS}

This type of research uses a quantitative approach which is a series of observations or measurement of the results using primary data in the form of a survey. Researchers designed this study to be able to understand, explain and analyze the correlation between the independent variable (independent) and the dependent variable (dependent). The analysis used in this study is to use relevant statistical data to test the hypothesis. The data obtained in this study can provide a clear picture of the object under study and later a conclusion can be made. The research variables described in terms of dimensions, indicators, and question items as data collection instruments can be seen in Table 2 .

Table 2. Operational Variables

$\begin{array}{lll}\text { Variable Type } & \text { Dimention } & \text { Indicator }\end{array}$




\begin{tabular}{|c|c|c|c|}
\hline \multirow{7}{*}{$\begin{array}{l}\text { Training }\left(X_{1}\right) \\
\text { Alan M.Saks \& } \\
\text { Robert R. Haccoun } \\
(2013)\end{array}$} & 1. Instructur & $\begin{array}{l}\text { a) Education } \\
\text { b) Material Knowledge }\end{array}$ & $\begin{array}{l}1-2 \\
3-4\end{array}$ \\
\hline & 2. Participant & a) Spirit & $5-6$ \\
\hline & & b) Selection & $7-8$ \\
\hline & 3. Material & Align with purpose & $9-10$ \\
\hline & & Align with participant's component & $11-12$ \\
\hline & 4. Purpose & Enhance creativity & $13-14$ \\
\hline & & Have firm target & $15-16$ \\
\hline \multirow{4}{*}{$\begin{array}{l}\text { Work Discipline } \\
\left(\mathrm{X}_{2}\right) \\
\text { Rivai \&Basri (2015) }\end{array}$} & 1. Attendance & Attendance frequency & $17-18$ \\
\hline & & Attendance punctuality & $19-20$ \\
\hline & 2. Work & Obedience of rules & $21-22$ \\
\hline & Obedience & Obedience of work standard & $23-24$ \\
\hline \multirow{4}{*}{$\begin{array}{l}\text { Organization } \\
\text { Committment }\left(\mathrm{X}_{3}\right) \\
\text { Schmerson }(2010)\end{array}$} & 1. Rational & Financial beneficiary & $25-26$ \\
\hline & & $\begin{array}{l}\text { Development and professional } \\
\text { beneficiary }\end{array}$ & $27-28$ \\
\hline & 2. Emotional & Assessment to work & $29-30$ \\
\hline & & Assessment to organization & $31-32$ \\
\hline \multirow{3}{*}{$\begin{array}{l}\text { Performance }(Y) \\
\text { Mathis \&Jackson } \\
(2008)\end{array}$} & 1. Quality & Work result perception & $33-34$ \\
\hline & & Work perfection perception & $35-36$ \\
\hline & 2. Quantity & $\begin{array}{l}\text { a) Production number } \\
\text { b) Productivity }\end{array}$ & $\begin{array}{l}37-38 \\
39-40\end{array}$ \\
\hline
\end{tabular}

Source: Data processed by researchers, 2020

\section{Population and Sample}

The population used in this study is all employees of the tire company, Building Plant T Department, in Banten, 703 employees. This study uses the Slovin formula in sampling. The determination of the amount can be done with simple formulas and calculations.

The Slovin formula for determining the sample is as follows:

$$
n=\frac{N}{1+N(e)^{2}}
$$

Remark:

$\mathrm{n}=$ sample size / number of respondents

$\mathrm{N}=$ Population size

$\mathrm{e}=$ tolerable percentage of allowance for accuracy of sampling error; $\mathrm{e}=0.1$

In the Slovin formula there are the following conditions:

The value of $\mathrm{e}=0.1(10 \%)$ for a large population

The value of $\mathrm{e}=0.2(20 \%)$ for a small population

The sample range that can be taken from the Solvin technique is between 10-20\% of the study population. The calculation to determine the research sample amount as follows: 


$$
\begin{aligned}
& n=\frac{703}{1+703(0,1)^{2}} \\
& n=87.5 \text { rounded to } 88
\end{aligned}
$$

In this study, the sampling technique used is non-probability sampling with a purposive sampling method. This non-probability sampling technique makes elements in the population do not have any inherent probability of being selected as sampling subjects.

\section{Data analysis}

Data analysis method used in this research is to use SmartPLS software version 3.2.7. Partial Least Square (PLS) is a study of structural equations on the basis of variance which together test the measurement model and test the structural model. To test the validity and reliability is carried out using a measurement model, while for the causality test is carried out using a structural model.

\section{RESEARCH RESULTS AND DISCUSSION \\ Respondent Characteristics}

The characteristics of the respondents in this study are presented in Table 3 as follows:

\begin{tabular}{|c|c|c|c|c|}
\hline No & Categori & Options & $\begin{array}{l}\text { Total } \\
\text { (person) }\end{array}$ & $\begin{array}{l}\text { Percentage } \\
(\%)\end{array}$ \\
\hline \multirow{2}{*}{1} & \multirow{2}{*}{ Gender } & Male & 88 & $100 \%$ \\
\hline & & Female & 0 & $0 \%$ \\
\hline \multirow{4}{*}{2} & \multirow{4}{*}{ Age } & $21-30$ & 45 & $51.14 \%$ \\
\hline & & $31-40$ & 28 & $31.82 \%$ \\
\hline & & $41-50$ & 15 & $17.04 \%$ \\
\hline & & $>50$ & 0 & $0 \%$ \\
\hline \multirow{3}{*}{3} & \multirow{3}{*}{ Status } & Single & 5 & $5.68 \%$ \\
\hline & & Married & 83 & $94.32 \%$ \\
\hline & & Widow/widower & 0 & $0 \%$ \\
\hline \multirow{4}{*}{4} & \multirow{4}{*}{$\begin{array}{l}\text { Monthly } \\
\text { expense }\end{array}$} & Rp.1.000.000 - Rp.3.000.000 & 10 & $11.36 \%$ \\
\hline & & Rp.3.000.001 - Rp.5.000.000 & 42 & $47.73 \%$ \\
\hline & & Rp.5.000.001 - Rp.7.000.000 & 33 & $37.5 \%$ \\
\hline & & $>$ Rp.7.000.000 & 3 & $3.41 \%$ \\
\hline \multicolumn{3}{|c|}{ Total Per Category } & 88 & $100 \%$ \\
\hline
\end{tabular}

Table 3. Number and Percentage of Respondent Categories

Source: Researcher processed data (2020)

\section{Descriptive Statistical Analysis of Research Variables}

The descriptive summary of the research variables is presented in Table 4 as follows:

Table 4. Descriptive Summary of the Value of Research Variables

\begin{tabular}{lc}
\hline Research Variabel & Variable Value \\
\hline Training & 4.11 \\
\hline Work Discipline & 4.47 \\
\hline Organization Committment & 4.12 \\
\hline Employee's Performance & 4.13
\end{tabular}

Source: Researcher processed data (2020) 
Table 4 shows the measurement results of the variables using the linkert scale (numbers 1 to 5, 1 indicates disagreement and 5 indicates agreement). Table 4 shows that the training variable has an average of 4.11. This shows in general that employees have high enthusiasm for the training provided by the company. Table 4 shows that work discipline has an average value of 4.47. This shows that in general employees have a very good perception of work discipline towards work attendance and regulations that follow work rules. Table 4 shows that the organizational commitment variable has an average score of 4.12. This shows that employees have good organizational perceptions and generally indicate that employees still have a strong enough desire to continue to be in the organization. Table 4 shows that the employee performance variable has an average value of 4.13. This shows in general that employees have a good perception of performance. Employees have the perception to produce good products in quality and quantity according to the standards set by the company.

\section{Evaluation of the Measurement Model (Outer Model) Reflective or Indicator Test}

Below is a picture of the calculation results of the measurement model with SEM PLS version 3.2.7, which shows the loading factor values on the each research variable indicators. The loading factor value used in this study is $>0.5$ so that if the loading factor value is $<0.5$ in the calculation results of the measurement model (outer model), the indicator will be excluded from the model.

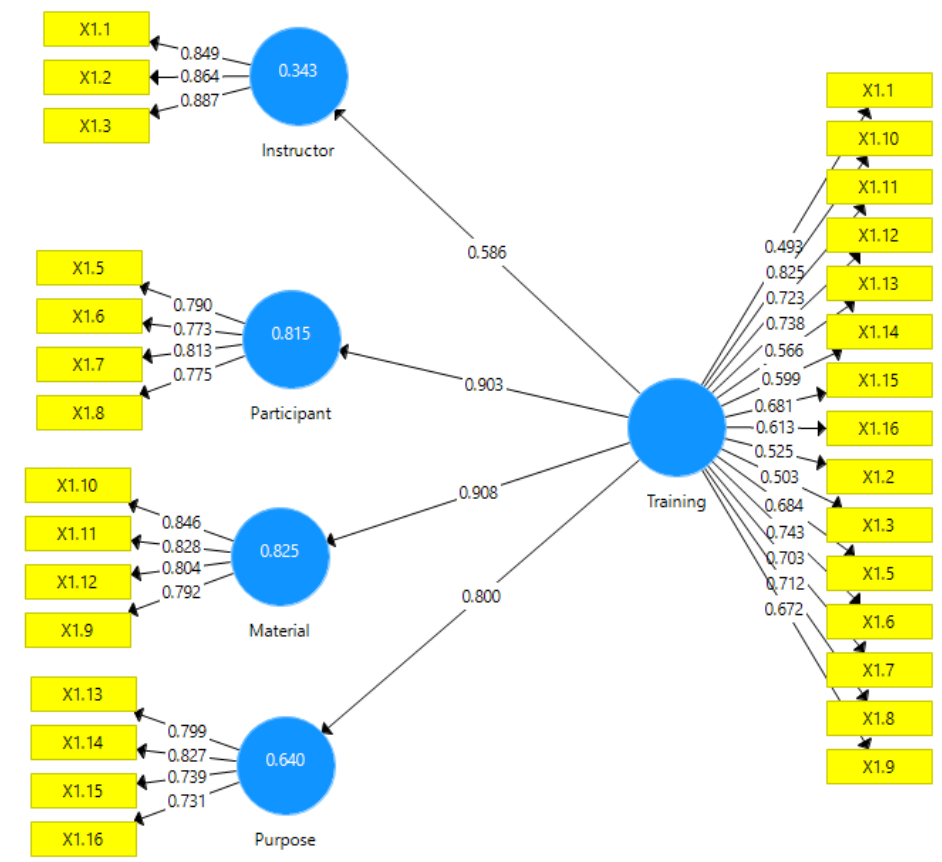

Figure 5. Loading Factor of Training Variables 


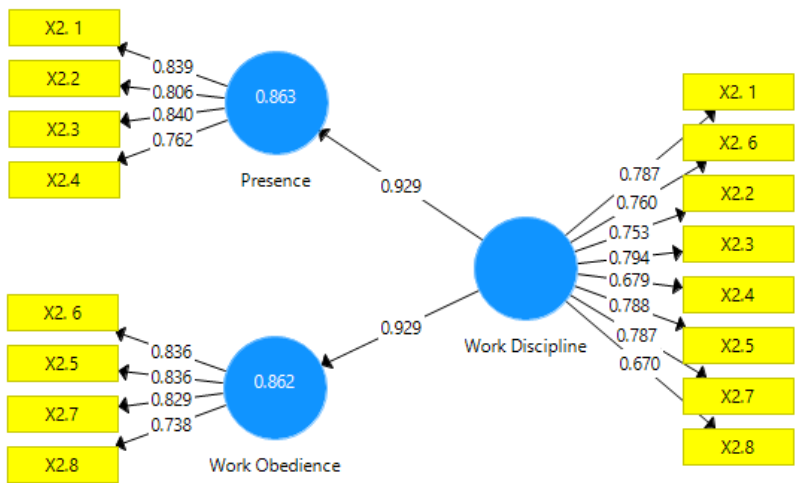

Figure 6. Loading Factor of Work Discipline Variable

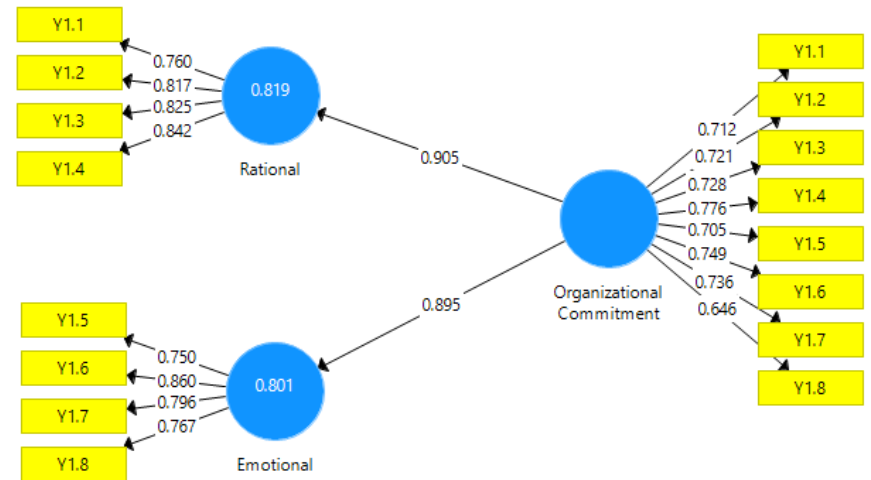

Figure 7. Loading Factors for Organizational Commitment Variables

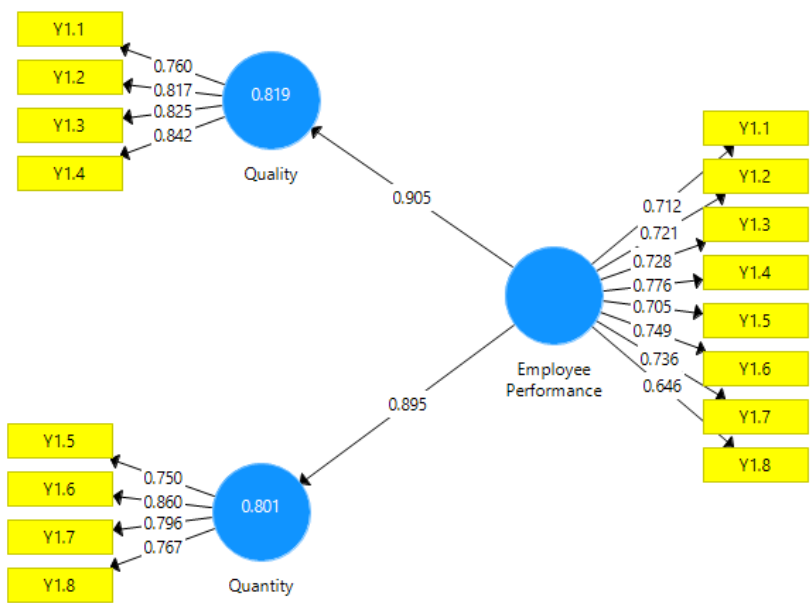

Figure 8. Loading Factors of Employee Performance Variables

Evaluation of convergent validity from checking internal consistency reliability can be seen from the value of Cronbach's Coefficient Alpha (CA) and Composite Reliability (CR) which shows the consistency value of each indicator in measuring its construct. The expected CA value is $>0.6$ and the expected CR value is $>0.7$. The results of the measurement of the $\mathrm{CA}$ and $\mathrm{CR}$ values meet the existing requirements and can be seen in Table 5. 
Table 5. Cronbach's Coefficient Alpha (CA) and Composite Reliability (CR) Value.

\begin{tabular}{lll}
\hline Variable & CA & CR \\
\hline Training & 0.903 & 0.917 \\
\hline Work Discipline & 0.891 & 0.912 \\
\hline Organizational Commitment & 0.836 & 0.874 \\
\hline Performance & 0.869 & 0.897 \\
\hline
\end{tabular}

Source: processed by researcher $(\mathbf{2 0 2 0})$

In Table 5, the Cronbach's alpha value is above 0.6 and composite reliability is above 0.70 . So it can be concluded that the construct or variable has good validity and reliability.

\section{Discriminant Validity Testing}

The validity of the indicators in each research variable can also be done by testing the discriminant validity, namely by checking the cross loading value, namely the correlation coefficient of the indicator on its construct compared to the correlation coefficient with other constructs. The value of the indicator correlation coefficient must be greater on its construct than other constructs. The test results can be seen in Table 6

Table 6. Results of Discriminant Validity Testing

\begin{tabular}{|c|c|c|c|c|c|}
\hline Item & Training & $\begin{array}{c}\text { Work } \\
\text { Discipline }\end{array}$ & $\begin{array}{c}\text { Organizational } \\
\text { Commitment }\end{array}$ & $\begin{array}{c}\text { Employee } \\
\text { Performance }\end{array}$ & Result \\
\hline $\mathrm{X} 1.1$ & 0.568 & 0.130 & 0.375 & 0.377 & Valid \\
\hline $\mathrm{X} 1.2$ & 0.596 & 0.282 & 0.421 & 0.412 & Valid \\
\hline $\mathrm{X} 1.3$ & 0.586 & 0.234 & 0.410 & 0.396 & Valid \\
\hline $\mathrm{X} 1.4$ & 0.473 & 0.288 & 0.407 & 0.306 & Valid \\
\hline $\mathrm{X} 1.5$ & 0.651 & 0.436 & 0.288 & 0.399 & Valid \\
\hline X1.6 & 0.708 & 0.436 & 0.406 & 0.480 & Valid \\
\hline $\mathrm{X} 1.7$ & 0.669 & 0.410 & 0.342 & 0.291 & Valid \\
\hline $\mathrm{X} 1.8$ & 0.705 & 0.457 & 0.392 & 0.464 & Valid \\
\hline X1.9 & 0.641 & 0.483 & 0.398 & 0.419 & Valid \\
\hline $\mathrm{X} 1.10$ & 0.804 & 0.502 & 0.469 & 0.494 & Valid \\
\hline $\mathrm{X} 1.11$ & 0.680 & 0.395 & 0.369 & 0.342 & Valid \\
\hline $\mathrm{X} 1.12$ & 0.730 & 0.496 & 0.451 & 0.521 & Valid \\
\hline $\mathrm{X} 1.13$ & 0.538 & 0.170 & 0.274 & 0.298 & Valid \\
\hline $\mathrm{X} 1.14$ & 0.580 & 0.259 & 0.307 & 0.294 & Valid \\
\hline $\mathrm{X} 1.15$ & 0.675 & 0.390 & 0.477 & 0.449 & Valid \\
\hline $\mathrm{X} 1.16$ & 0.606 & 0.347 & 0.363 & 0.296 & Valid \\
\hline $\mathrm{X} 2.1$ & 0.346 & 0.788 & 0.499 & 0.431 & Valid \\
\hline X2.2 & 0.411 & 0.754 & 0.462 & 0.500 & Valid \\
\hline $\mathrm{X} 2.3$ & 0.399 & 0.771 & 0.398 & 0.499 & Valid \\
\hline X2.4 & 0.337 & 0.682 & 0.417 & 0.542 & Valid \\
\hline $\mathrm{X} 2.5$ & 0.382 & 0.772 & 0.442 & 0.486 & Valid \\
\hline X2.6 & 0.410 & 0.760 & 0.421 & 0.457 & Valid \\
\hline X2.7 & 0.356 & 0.753 & 0.310 & 0.464 & Valid \\
\hline X2.8 & 0.637 & 0.725 & 0.645 & 0.512 & Valid \\
\hline X3.1 & 0.350 & 0.414 & 0.574 & 0.392 & Valid \\
\hline
\end{tabular}




\begin{tabular}{|c|c|c|c|c|c|}
\hline Item & Training & $\begin{array}{c}\text { Work } \\
\text { Discipline }\end{array}$ & $\begin{array}{c}\text { Organizational } \\
\text { Commitment }\end{array}$ & $\begin{array}{c}\text { Employee } \\
\text { Performance }\end{array}$ & Result \\
\hline X3.2 & 0.489 & 0.530 & $\mathbf{0 . 7 0 0}$ & 0.519 & Valid \\
\hline X3.3 & 0.363 & 0.332 & $\mathbf{0 . 7 4 1}$ & 0.443 & Valid \\
\hline X3.4 & 0.354 & 0.155 & $\mathbf{0 . 5 2 2}$ & 0.239 & Valid \\
\hline X3.5 & 0.375 & 0.354 & $\mathbf{0 . 7 0 4}$ & 0.502 & Valid \\
\hline X3.6 & 0.490 & 0.478 & $\mathbf{0 . 7 6 0}$ & 0.465 & Valid \\
\hline X3.7 & 0.397 & 0.542 & $\mathbf{0 . 7 3 3}$ & 0.570 & Valid \\
\hline X3.8 & 0.497 & 0.460 & $\mathbf{0 . 6 9 9}$ & 0.458 & Valid \\
\hline Y1.1 & 0.403 & 0.504 & 0.545 & $\mathbf{0 . 7 2 0}$ & Valid \\
\hline Y1.2 & 0.443 & 0.475 & 0.446 & $\mathbf{0 . 7 1 6}$ & Valid \\
\hline Y1.3 & 0.394 & 0.406 & 0.453 & $\mathbf{0 . 7 2 4}$ & Valid \\
\hline Y1.4 & 0.482 & 0.474 & 0.527 & $\mathbf{0 . 7 7 4}$ & Valid \\
\hline Y1.5 & 0.487 & 0.556 & 0.464 & $\mathbf{0 . 7 0 6}$ & Valid \\
\hline Y1.6 & 0.413 & 0.456 & 0.449 & $\mathbf{0 . 7 4 4}$ & Valid \\
\hline Y1.7 & 0.429 & 0.507 & 0.469 & $\mathbf{0 . 7 3 2}$ & Valid \\
\hline Y1.8 & 0.510 & 0.374 & 0.512 & $\mathbf{0 . 6 5 7}$ & Valid \\
\hline
\end{tabular}

Source: Data processed by Researchers (2020)

Based on the results of discriminant validity testing, as shown in Table 6, it shows that there are 40 indicators that are proven to show the correlation coefficient value of the construct itself which is greater than other constructs. Statement items that do not meet these criteria are removed from the model.

\section{Evaluation of the Structural Model (Inner Model) or Hypothesis Testing Evaluating the Path Coefficient Value}

To evaluate the path coefficient value, based on the results of calculations using the calculate SmartPLS version 3.2.7 bootstrapping, the path coefficient results are obtained which describe the strength of the relationship between constructs / variables as shown in Figure 9 and also Table 7. 


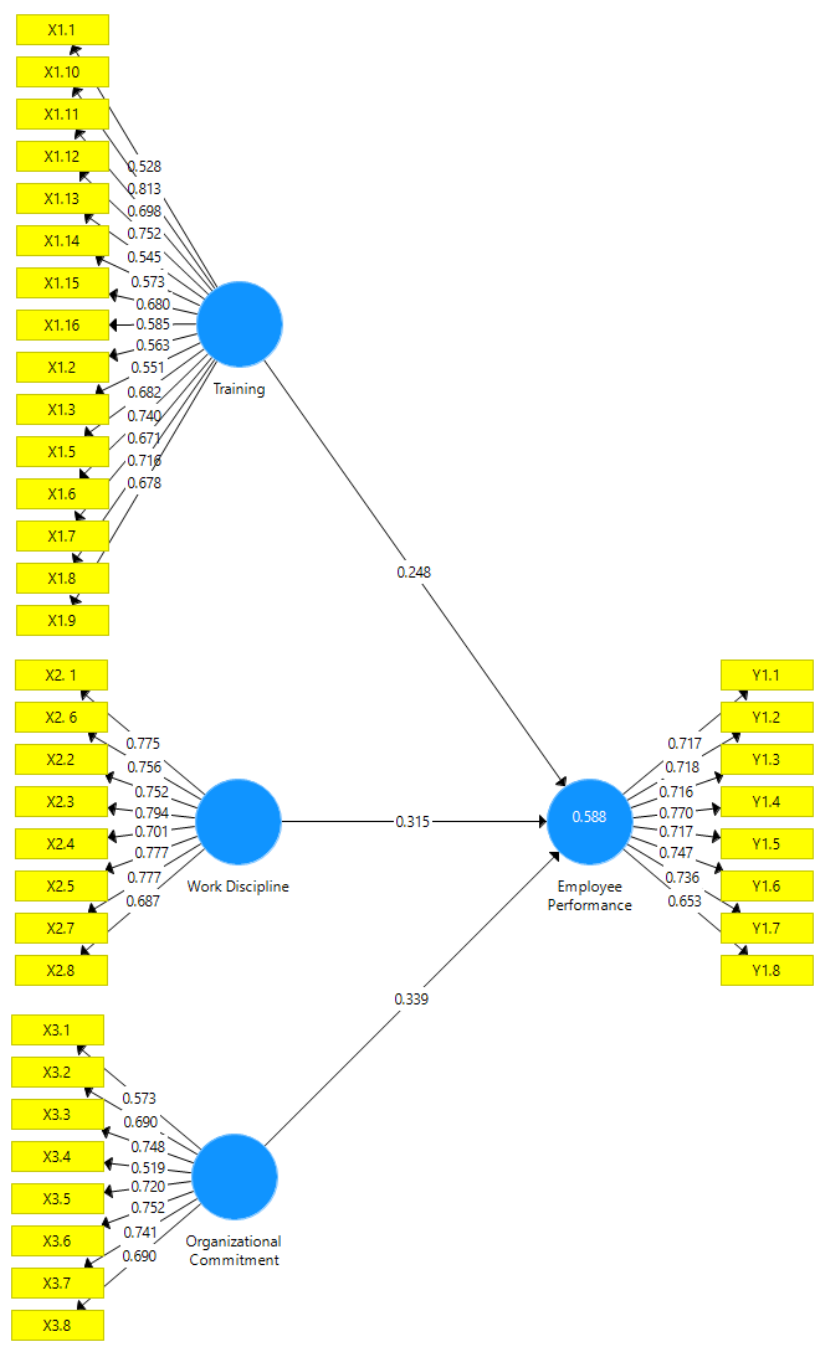

Figure 9.Calculation results of the path coefficient Model Measurement (Inner Model)

Table 7. Path Coefficient Testing Results

\begin{tabular}{lcccccc}
\hline \multicolumn{1}{c}{ Path } & $\begin{array}{c}\text { Original } \\
\text { Sample }(\mathrm{O})\end{array}$ & $\begin{array}{c}\text { Sample } \\
\text { Mean } \\
(\mathrm{M})\end{array}$ & $\begin{array}{c}\text { Standard } \\
\text { Deviation } \\
(\text { STDEV })\end{array}$ & $\begin{array}{c}\text { T Statistics } \\
(\mid \mathrm{O} / \text { STDEV })\end{array}$ & $\begin{array}{c}\mathrm{T} \\
\text { Table }\end{array}$ & $\begin{array}{c}\mathrm{P} \\
\text { Values }\end{array}$ \\
\hline $\begin{array}{l}\text { Training -> Employee } \\
\text { Performance }\end{array}$ & 0.248 & 0.256 & 0.110 & 2.265 & 1.988 & 0.024 \\
\hline $\begin{array}{l}\text { Work Discipline -> Employee } \\
\text { Performance }\end{array}$ & 0.315 & 0.309 & 0.101 & 3.110 & 1.988 & 0.002 \\
\hline $\begin{array}{l}\text { Organizational Commitment -> } \\
\text { Employee Performance }\end{array}$ & 0.339 & 0.354 & 0.098 & 3.458 & 1.988 & 0.001 \\
\hline
\end{tabular}

Figure 9 and Table 7 show that the path that has the least effect is the training path on employee performance. This shows that training has a smaller contribution to employee performance compared to work discipline and organizational commitment variables. Training turns out to have a smaller contribution because training is not an attitude of self-initiation, but an initiation from a company to improve employee performance. Training which is held regularly and continuously will increase employee awareness and expertise to increase work productivity.

\section{Evaluating $\mathbf{R}^{2}$ Value}


The value of $\mathrm{R}^{2}$ shows the level of determination of the exogenous variables (training, work discipline, organizational commitment) to the endogenous variables (employee performance). There are 3 criteria for the value of $\mathrm{R}^{2}$, namely: 0.67 means strong, 0.33 means moderate and 0.19 means weak. The results of the calculated $\mathrm{R}^{2}$ and $\mathrm{F}$ values are shown in Table 8.

Table 8 R Square Test Results

\begin{tabular}{|c|c|c|c|c|}
\hline Path & R square & $\begin{array}{c}\text { R square } \\
\text { adjusted }\end{array}$ & $\begin{array}{c}\text { F } \\
\text { Arithmatic }\end{array}$ & F table \\
\hline Employee performance & 0.588 & 0.573 & 38.89 & 2.71 \\
\hline
\end{tabular}

Source: Data processed by Researchers (2020)

Table 8 shows the level of determination of exogenous variables against endogenous variables categorized as moderate in all paths.

\section{Measuring the Effect Size $\mathbf{f}^{2}$}

The purpose of measuring the effect size $\mathrm{f}^{2}$ is to see the size of the influence of exogenous latent variables on endogenous latent variables or to see the goodness of the model. There are 3 criteria for the value of $\mathrm{f}^{2}$, namely: 0.35 means strong, 0.15 means moderate and 0.12 means weak. The results of the calculation of the effect size (f square) with Smart PLS version 3.2.7 are in Table 9 below.

Table 9. Effect Size $\mathbf{F}^{2}$

\begin{tabular}{|l|c|}
\hline \multicolumn{1}{|c|}{ Variable } & Employee Performance \\
\hline Training & 0.089 \\
\hline Work Discipline & 0.140 \\
\hline Organizational Discipline & 0.153 \\
\hline
\end{tabular}

Source: Data processed by Researchers (2020)

Table 9 shows that the training and work discipline variables have a weak influence on the performance variable, while the organizational commitment variable has a moderate effect on the performance variable.

\section{Validating the Overall Structural Model with the Goodness of Fit Index (GoF) and Predictive Relevance $\left(\mathbf{Q}^{2}\right)$}

The purpose of conducting Goodness of Fit Index (GoF) testing is to validate the combined performance of the measurement model (outer model) and structural model (inner model). The provisions of the GoF category are small GoF values $=0.1$, medium $\mathrm{GoF}=0.25$ and Large $\mathrm{GoF}=0.36$. GoF calculations are carried out using the following formula.

$$
\mathrm{GoF}=\sqrt{ } \mathrm{AVE} * \mathrm{R}^{2}
$$

The purpose of conducting predictive relevance $\left(\mathrm{Q}^{2}\right)$ testing is to validate the model. If the endogenous latent variable has a predictive relevance $\left(\mathrm{Q}^{2}\right)$ value that is greater than 0 (zero), then the exogenous latent variable can be considered capable of predicting the endogenous variable or it can be said that this model is considered to have good predictive relevance. $\mathrm{Q}^{2}$ calculation is done with the following formula. The results of the GoF and $\mathrm{Q}^{2}$ calculations are shown in Table 10.

$$
\mathrm{Q}^{2}=1-\left(1-\mathrm{R}_{1}{ }^{2}\right)\left(1-\mathrm{R}_{2}{ }^{2}\right)
$$


Table 10. GoF and $Q^{2}$ Test Results

\begin{tabular}{|l|c|c|}
\hline \multicolumn{1}{|c|}{ Type of Measurement } & GoF & $\mathrm{Q}^{2}$ \\
\hline Calculation Result & 0.5377 & 0.588 \\
\hline Interpretation & Large & Good \\
\hline
\end{tabular}

Source: Data processed by Researchers (2020)

The GoF and $\mathrm{Q}^{2}$ test results can be seen in Table 10. Table 10 shows that the results of the calculation of the Goodness of Fit Index (GoF) show a value of 0.5377. Based on these results, it can be concluded that the combined performance between the measurement model (outer model) and the structural model (inner model) is a large GoF, because the Goodness of Fit Index (GoF) value is more than 0.36 (large scale GoF).

In this research model, endogenous latent variables have a predictive relevance $\left(Q^{2}\right)$ value greater than 0 (zero) so that the exogenous latent variables as explanatory variables are able to predict the endogenous variables, namely employee performance, or in other words, this calculation proves that this model is considered to have good predictive relevance.

\section{Results of the Influence of Independent Variables on Dependent Variables}

The results of statistical calculations of the effect of the independent variable on the dependent variable are presented in Table 11 and Table 12. Table 11 presents the results of the significance effect test between the two variables. The measuring instrument used is the path coefficient, the comparison of $\mathrm{T}$ count with the $\mathrm{T}$ table and also the comparison of $\mathrm{P}$ count and $\mathrm{P}$ standard. If the magnitude of $\mathrm{T}$ is greater than $\mathrm{T}$ table and the quantity of $\mathrm{P}$ is smaller than the standard P, then the hypothesis is accepted. Vice versa. A more complete explanation of Table 11 and Table 12 will be explained in the discussion section.

Table 11. Results of the Influence of Independent Variables on Dependent Variables (Part I)

\begin{tabular}{|c|c|c|c|c|c|}
\hline Hypothesis & Interpretation & $\begin{array}{l}\text { Coefficient } \\
\text { path }\end{array}$ & $\begin{array}{c}\mathrm{T} \text { arithmatic }> \\
\mathrm{T} \text { table }\end{array}$ & $\begin{array}{c}\mathrm{P} \text { arithmetic } \\
\text { (Compared with } \\
\text { P Standard } \\
0.05)\end{array}$ & Conclusion \\
\hline $\mathrm{H}_{1}$ & $\begin{array}{c}\text { Training has a } \\
\text { significant effect on } \\
\text { employee performance }\end{array}$ & 0.248 & $2.265>1.988$ & 0.0024 & Received \\
\hline $\mathrm{H}_{2}$ & $\begin{array}{l}\text { Work discipline has a } \\
\text { significant effect on } \\
\text { employee performance }\end{array}$ & 0.315 & $3.110>1.988$ & 0.002 & Received \\
\hline $\mathrm{H}_{3}$ & $\begin{array}{c}\text { Organizatinal } \\
\text { Commitment has a } \\
\text { significant effect on } \\
\text { employee performance }\end{array}$ & 0.339 & $3.458>1.988$ & 0.001 & Received \\
\hline
\end{tabular}

\section{Source : Smart PLS}

Table 11 shows several conclusions. First, training has a significant effect on employee performance. Second, work discipline has a significant effect on employee performance. Third, organizational commitment has a significant effect on employee performance.

Table 12 shows the results of the hypothesis test, namely the $\mathrm{R}^{2}$ value of the employee performance variable is 0.588 with $\mathrm{F}$ arithmatic greater than $\mathrm{F}$ table, it is concluded that the variables of training, work discipline and organizational commitment simultaneously have a significant effect on employee performance variables. 
Table 12. Results of the Influence of Independent Variables on Dependent Variables (Part II)

\begin{tabular}{ccccc}
\hline Hypothesis & Interpretation & R Square & $\begin{array}{c}\text { F arithmatic }> \\
\text { F table }\end{array}$ & Conclusion \\
\hline $\mathrm{H}_{4}$ & $\begin{array}{c}\text { Training, work discipline and } \\
\text { organizational commitment } \\
\text { have a significant effect on } \\
\text { employee performance }\end{array}$ & 0.588 & $38.89>2.71$ & Received \\
\hline
\end{tabular}

\section{Inter-Dimensional Correlation Analysis}

The inter-dimensional correlation matrix is intended to determine the dimensions of the independent variable $\mathrm{X}$ (training, work discipline, organizational commitment) which have the highest correlation value with the dimensions of the dependent variable $\mathrm{Y}$ (employee performance). The correlation between dimensions is shown in Table 13.

Table 13. Results of the Correlation Matrix Between the Dimensions of Independent and Dependent Variables

\begin{tabular}{|l|c|c|}
\hline \multicolumn{1}{|c|}{ Dimention } & Quality & Quantity \\
\hline Instructure & 0.446 & 0.313 \\
\hline Participant & 0.359 & 0.399 \\
\hline Material & 0.350 & 0.421 \\
\hline Purpose & 0.359 & 0.318 \\
\hline Attendance & 0.495 & 0.464 \\
\hline Work obedience & 0.412 & 0.400 \\
\hline Rational & 0.505 & 0.421 \\
\hline Emotional & 0.500 & 0.533 \\
\hline
\end{tabular}

Source: Data processed by Researchers (2020)

Table 13 shows that the rational dimension has the greatest correlation with employee performance related to product quality, compared to the dimensions that exist in the training and work discipline variables. The emotional dimension has the greatest correlation with employee performance related to product quantity, compared to the dimensions that exist in the training and work discipline variables.

\section{Discussion}

The results show that training has a significant effect on employee performance. The results of this study indicate that the frame work training provided by the company motivates employees to work better. Frame work is a training given to employees related to work instructions which aims to ensure that the work results of employees are in accordance with company expectations. The instructor dimension has the greatest correlation with employee performance related to product quality. The instructor's ability to explain and deliver material is good enough to make training participants understand the essence and purpose of the training provided and motivate employees to improve their performance. The company's policy of choosing instructors who have certification that fits the frame work training material is a good decision for training to be effective. The material dimension has the greatest correlation with employee performance related to product quantity. The frame work training material provided is designed in a complete and easy to understand manner so that 
employees become skilled in completing their work. Employees who have attended the framework training have a strong desire to be able to increase the quantity and quality of their work output. Increasing employee job skills has a direct impact on the number of product units that employees can produce.

The results show that work discipline has a significant effect on employee performance. The results of this study indicate that employees always try to come to work. The attendance dimension has the greatest correlation with employee performance with regard to product quality and quantity. This is because the high level of employee attendance will have an impact on the implementation of work in accordance with a predetermined plan. Employees who have high work discipline are accustomed coming to work on time and being present in carrying out their job duties. The absence of employees will cause harm to the company. Employees who have low work discipline are accustomed to arriving late and not being present in carrying out their duties will have a big effect on performance, because several additional workers must be hired to meet performance targets. This causes a decrease in employee performance which results in the company not achieving the quantity of output expected by the company. Additional or replacement workers cause a decrease in employee performance results in terms of quality. This is because additional workers are workers who get overtime and work more than they should. Working more than the specified working hours has an impact on weakened physical abilities due to fatigue, resulting in poor quality products.

The results show that organizational commitment has a significant effect on employee performance. The rational dimension has the greatest correlation with employee performance related to product quality. This is because employees feel that their current job is helping to meet their daily needs, giving rise to a sense of concern for the resulting performance output. Employees feel the company provides elements of security and stability, attractive jobs and competitive wages. This is what increases the sense of wanting to contribute and have a high commitment to employees so that it has an impact on concern for the quality of the output produced. The emotional dimension has the greatest correlation with employee performance in terms of product quantity. In general, employees have a pretty good emotional organizational commitment. Employees feel that their current job has benefits for others. Employees also have a sense of pride in their work and company. This feeling is what spurs the enthusiasm and work ethic of employees in meeting the product quantity targets that have been determined by the company. Employees with high commitment will be responsible for their work.

The results show that the variables of training, work discipline and organizational commitment simultaneously had a significant effect on employee performance variables with a simultaneous influence of $58.8 \%$ while the remaining $41.2 \%$ of employee performance was influenced by other factors outside of training, work discipline and commitment. organization. Based on these results, the researchers concluded that training instructors, training participants, training materials, training objectives, work attendance, work obedience, rational commitment and emotional commitment affect the quality and quantity of employee performance.

\section{CONCLUSIONS AND RECOMMENDATIONS Conclusion}


Based on the results of previous research and discussion, several conclusions can be drawn, namely: (1) training has a significant effect on employee performance, (2) work discipline has a significant effect on employee performance, (3) organizational commitment has a significant effect on employee performance, (4) training, discipline work and organizational commitment have a significant effect on employee performance.

\section{Recommendation}

Based on the results of the correlation, the recommendation that can be given to complement the results of this study are as follows:

1. For the company

a. Companies are expected to maintain and develop effective and efficient training methods. Companies should be consistent in implementing training outputs which include adding insight and knowledge of employees and increasing skills. Companies should design a training system that can make changes to employee behavior even better, which can be seen from their daily attitude to continue to apply the training material that has been provided in their work activities. Attractive material designs such as the use of animated videos, group games, use of audio-visual media and communicative instructors who have the appropriate qualifications can make the training program effective and increase the abilities of the participants. Continuous training design should be held regularly to motivate employees to improve their performance.

b. Companies need to maintain the sense of discipline that employees have by creating and monitoring the implementation of rules on employee discipline. In addition, the rules for employee discipline must be clearly and precisely designed so that they can be used as a reference for all employees. Work discipline rules must be applied by employees during work so that later it will lead to high disciplinary behavior habits.

c. Companies need to maintain and enhance psychological contracts with their employees so that they create rational and emotional commitment to employees. Companies should undertake an attractive and competitive wage strategy and make efforts to improve the emotional relationship between the company and employees. This is intended to create a sense of employee loyalty to the company and have an impact on improving employee performance.

\section{For Further Researchers}

a. It is hoped that further researchers can develop this research by adding other variables, such as leadership, work environment, workload, organizational culture, compensation and work motivation.

b. It is hoped that further researchers can develop research by adding mediating variables to provide a more in-depth explanation of performance with the factors that influence it.

\section{BIBLIOGRAPHY}

Afrot NN. (2018). Effect of Training on Employee Performance - A Study on Banking Sector, Tangail Bangladesh. Global Journal of Economics and Business Vol.4, No.1. Karyawan PT Adaro Energy Tbk. Telaah Bisnis Vol. 16, No.2. 
Bateman TS and Scott A Snell. (2014). Manajemen Edisi 10 Buku 2. Penerbit Salemba Empat: Jakarta

Darshani RKND. (2018). The Impact of Training and Development on Employee Perfomance. International Journal of Research Publications Vol.2, No.1.

Dhesty K, A.L Rantetampang and Happy Lumbantobing. (2016). Relationship of Work Discipline, Leadership, Training and Motivation to Performance Employees Administration Abepura Hospital Papua 2015. Internatioan Journal of sciences Vol.26, No.1.

Fahmi I. (2010). Manajemen Kinerja Teori dan Aplikasi. Penerbit Alphabeta. Bandung.

Gomez-Meija LR, David B Balkin, Robert L Cardy. (2010). Managing Human Resource. Pearson Education. Inc: New Jersey.

Greenberg Jerald. (2011) Behavior in Organization $10^{\text {th }}$ edition.. Pearson Education Limited. England.

Hendarawan YK, Salamah Wahyuni. (2016). Pengaruh Pelatihan-Pengembangan dan Motivasi terhadap Peningkatan Kinerja Pegawai dengan Mediasi komitmen Organisasi. Jurnal Bisnis dan Manajemen Vol.16, No.1.

Hersona S, Iwan Sidaharta. (2017). Influence of Leadership Function, Motivation and Work Discipline on Employees Performance. Journal of Applied Management Vol.15 No.3.

Ibrahim AA. (2016). The Impact of Training and Development on Employee Performance (United Bottling Company Case Study) In Mogadishu-Somalia. EPRA International Journal of Multidisciplinary Research Vol. 2, No.10.

Idris M. (2018). The Impact of Education and Training, Work Discipline and Organizational Culture on Employee Performance: The Study of Disaster Management and Fire Departement in Palembang City, Indonesia. International Journal of Human Resources Studies Vol.8, No.3.

Jumawan and Martin Tanjung Mora. (2018). Pengaruh Pelatihan dan Pengembangan Karier terhadap Kinerja Karyawan Perusahaan Korporasi. Jurnal Riset dan Manajemen Fakultas Ekonomi UNIAT Vol.3, No.3.

Mangkunegara AP, Abdul Waris. (2015). Effect of Training, Competence and Discipline on Employee Perfomance In Company (Case Study in PT. Asuransi Bangun Askrida). $2^{\text {nd }}$ Global Conference on Business and Social Science.

Mathis RL and John H Jackson. (2008). Human Resource Management $12^{\text {th }}$ Edition. Thomson Corporation: United States.

Meilany P, Mariaty Ibrahim. (2015). Pengaruh Disiplin Kerja terhadap Kinerja Karyawan (Kasus Bagian Operasional PT. Indah Logistik Cargo Cabang Pekanbaru). Jom Fisip Vol.2, No.2.

Moorhead Gregory dan Griffin Ricky W. (2013). Manajemen Sumber Daya Manusia dan Organisasi. Jakarta Selatan: Salemba Empat.

Naseem. Sikandar, Hameed dan Khan. (2012). Factors Affecting Employee Performance, Evidence from Pakistan: Science Series Data Report. Science Series Data Report Vol.4, No.6.

Pratama MAP and Fareshti Nurdiana Dihan (2017). Pengaruh Komitmen Organisasional dan Disiplin Kerja terhadap Kinerja Karyawan melalui Kepuasan kerja sebagai Variable Intervening. Jurnal Bisnis Teori dan Implementasi Vol. 8, No.2.

Putri DO, Triatmanto B, Setiyadi S. (2017). The Effect of Ocupational Health And Safety, Work Environment And Discipline On Employee Performance In A Consumer Goods Company. International Conference on Industrial and System Engineering

Rahinnaya R and Mirwa Surya Perdhana. (2016). Analisis Pengaruh Pelatihan dan Pengembangan, Kompensasi serta Kompetensi Terhadap Kinerja Kraywan (Studi pada PT POS Semarang). Diponegoro Journal of Management Vol.5, No.3. 
Razak A, Sarpan and Ramlan. (2018). Effect of Leadership Style, Motivation and Work Discipline On Employee Performance in PT. ABC Makassar. International Review of Management and Marketing

Renyut BC, H. Basri Modding. Jobhar and Sukmawati St Bima. (2017). The Effect of Organizational Commitment, Competence and Job satisfaction and Employee Performance in Maluku Governer's Office. IOSR Journal of Business and Management Vol.19, No.11.

Rosmadi MLN. (2018). Pengaruh Pelatihan, Disiplin dan Pengembangan Karir terhadap Kinerja Karyawan Outsourcing PT. Garda Utama. Jurnal Bisnis Manajemen dan Informatika; Vol.14.

Saks AM and Haccoun RR. (2013) Managing Performance through Training and Development. Nelson Education Ltd: United States.

Salah MRA. (2016). The Impact of Training and Development on Employees Performance and Productivity. International Journal of Management Sciences and Business Research. Vol.5,No.7.

Sari SY. (2017). Pengaruh Disiplin Kerja, Lingkungan Kerja dan Motivasi Kerja terhadap Kinerja Karyawan pada PT. Tigaraksa Satria Tbk Cabang Padang. Jurnal EKOBISTEK Fakultas Ekonomi Vol.6, No.1.

Sawitri D, Endang Suswati and Khasbulloh Huda. (2016). The Impact of Job Satisfaction, Organization Commitment, Organization Citizenship Behavior (OCB) on Employee's Performance. International Journal of Organization Innovation Vol 9, No.2.

Schermerhorn JR. (2010) Introduction to Management $10^{\text {th }}$ edition. John Wiley \& Sons (Asia) Pte Ltd: Hoboken.

Setiawan A (2013). Pengaruh Disiplin Kerja dan Motivasi terhadap Kinerja Karyawan pada Rumah Sakit Umum Daerah Kanjuruhan Malang. Jurnal Ilmu Manajemen Vol.1 No.4.

Sekaran Uma and Roger Bougie. (2019). Metode Penelitian untuk Bisnis Edisi 6 Buku 1. Salemba Empat: Jakarta Selatan.

Sekaran Uma and Roger Bougie. (2019). Metode Penelitian untuk Bisnis Edisi 6 Buku 2. Salemba Empat: Jakarta Selatan.

Sudarmanto. (2009). Kinerja dan Pengembangan Kompetensi SDM. Pustaka Pelajar: Yogyakarta.

Sulaefi. (2017). Pengaruh Pelatihan dan Pengembangan terhadap Disiplin Kerja dan Kinerja Karyawan. Jurnal Manajemen dan Kewirausahaan Vol.5, No.1.

Yamanie IY and Syaharuddin. (2016). Pengaruh Penilaian Prestasi Kinerja, Komitmen Organisasi dan Disiplin Kerja terhadap Kinerja Karyawan pada PT. Pelabuhan Indonesia IV Cabang Samarinda. Jurnal Manajemen Vol.8.

Younas W, Muhammad Farooq, Faisal Khalil-Ur-Rehman dan Aneeqa Zreen. (2018). The Impact of Training and Development on Employee Performance. IOSR Journal of Business Management Vol.20, No 7.

Vipraprastha T, I Nengah Sudja Anik Yuesti. (2018). The Effect of Transformational Leadership and Organizational Commitment to Employee Performance with Citizenship Organization (OCB) Behavior as Intervening Variables (At PT Sarana Arga Gemeh Amerta in Denpasar City). International Journal of Contempory Research and Review Vol. 9, No.2. 